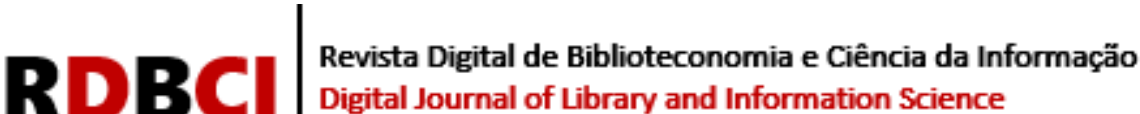

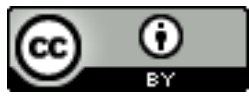

\section{As mediações como objeto de pesquisa em periódicos brasileiros da Ciência da Informação e áreas correlatas}

\author{
Eliane Cristina de Freitas Rocha ${ }^{1}$ iD https://orcid.org/0000-0002-4606-016X \\ ${ }^{1}$ Universidade Federal de Minas Gerais, Belo Horizonte, MG, Brasil / e-mail: prof.lili.rocha@gmail.com
}

\section{RESUMO}

Este artigo aborda a temática das mediações de maneira multidimensional - mediação vertical, institucional e horizontal - e apresenta como estas dimensões têm sido abordadas na Ciência da Informação (CI) e Biblioteconomia e em áreas correlatas (Arquivologia, Museologia e Sistemas de Informação) em publicações científicas em língua portuguesa. Inicialmente, o conceito de mediação é apresentado em suas diversas manifestações, privilegiando seus eixos horizontal e vertical. Em seguida, foi realizado um estudo panorâmico dos resumos de artigos completos sobre a temática presentes em 11 periódicos da CI e Biblioteconomia, seis da Museologia, dois da Arquivologia e um de Sistemas de Informação, em língua portuguesa, nos últimos dez anos (entre janeiro de 2007 a outubro de 2017). Por meio da análise de conteúdo dos assuntos presentes nos resumos, é possível afirmar que há grande variedade de conceitos e abordagens das mediações. O conceito geral de mediação é bastante amplo e genérico, e tem sido abordado, na CI e Museologia, para se referir tanto a processos macrossociais que se referem ao papel das instituições museu e biblioteca na ordem social, abrangendo ações culturais, quanto para processos institucionais de organização de documentos, além de processos situacionais que envolvem ações educativas e serviços prestados a usuários e públicos. Já os periódicos específicos de Arquivologia timidamente destacam a temática, que é praticamente ausente nos periódicos de Sistemas de Informação.

PALAVRAS-CHAVE

Ciência da Informação. Biblioteconomia. Museologia. Arquivologia. Sistemas de Informação.

\section{Mediation as research object in Brazilian Information Science and correlated areas journals}

\begin{abstract}
This article addresses the theme of mediations in a multidimensional way - vertical, institutional and horizontal mediation - and presents how these dimensions have been addressed in Information Science (CI) and Library Science and related areas (Archival Science, Museology and Information Systems) in publications in Portuguese. At first, the mediation concept is presented in its different manifestations, privileging its horizontal and vertical axis. Then, it was undertaken a panoramic study on abstracts of full articles published about that theme in 11 LIS, six Museology, two Archival Science and one Information Systems Journals, in the last ten years (articles published from January 2007 to October 2017). Through content analysis of those abstracts, it is possible to affirm the great variety of concepts and approaches of mediation. The general mediation concept is wide and generic, and has been approached in LIS and Museology, in reference as to macrosocial processes about the role of museums and library in social order, covering cultural actions, as to institutional process related do document organizing, and also situational processes related to educative actions and services offered to users and publics. By their turn, Archival Science Journals modestly present the theme, which one is almost absent in Information System Journals.
\end{abstract}

\section{KEYWORDS}

Information Science. Librarianship. Museology. Archival Science. Information Systems. 


\section{RDBCI Digital Journal of Library and Information Science}

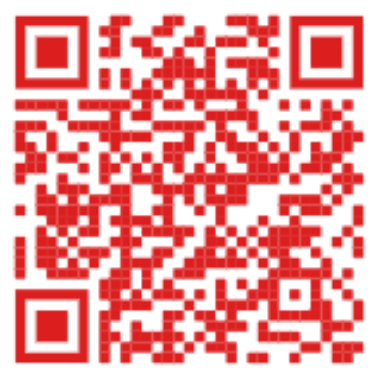

JITA: AA. Library and information science as a field 


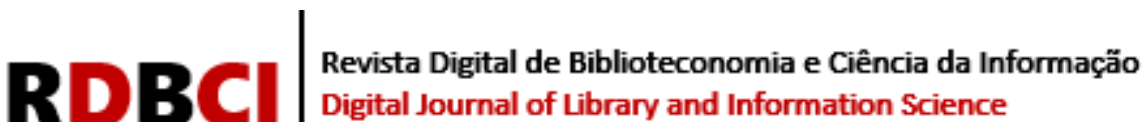

\section{INTRODUÇÃO}

Este artigo objetiva apresentar um panorama geral de como as mediações, enquanto temática transversal na área de Ciência da Informação (CI), Museologia, Arquivologia e Biblioteconomia, tem sido abordada nessas disciplinas. Também se procurou levantar a presença de tão propalada temática em periódicos da área de Sistemas de Informação, outra área considerada interdisciplinar com a CI por Silva e Ribeiro (2008).

A temática da mediação tem sido destacada como uma das grandes áreas de interesse de pesquisa na CI (ALMEIDA JÚNIOR, 2009), e também é fortemente presente no campo de estudos da Comunicação Social. No âmbito da inserção da CI como ciência social aplicada, merece destaque a importância de se estudar as atividades mediadoras que possibilitam as relações dos usuários e públicos com a informação e os equipamentos informacionais e culturais. A mediação poderia ser vista, nesta direção, como campo de estudo e intervenção inter e transdisciplinar. No entanto, há lacunas na compreensão da mediação, especialmente pelo seu conceito demasiadamente ampliado e multifacetado.

Diante das dificuldades de abordagem conceitual das mediações, foi realizada uma pesquisa bibliográfica que procurou levantar como a temática se apresenta em periódicos das áreas da CI e Biblioteconomia, Arquivologia, Museologia e Sistemas de Informação. Embora outras áreas, como a da Comunicação Social, sejam interdisciplinares à CI e de grande interesse para a pesquisa, optou-se por restringir a pesquisa empírica às áreas supracitadas, pois estas são as áreas de atuação da pesquisadora em ensino de graduação, dados os contornos da atuação institucional da Escola de Ciência da Informação da UFMG.

Para empreender o estudo, foi necessário trabalho exaustivo de revisão bibliográfica sobre as mediações e suas dimensões, o qual é apresentado de maneira sumária na seção 2 , seguinte. Tendo sido esclarecidas as dimensões conceituais do conceito de mediação, foi realizado levantamento bibliográfico de todos os artigos de periódicos das áreas de CI, Biblioteconomia, Museologia, Arquivologia e Sistemas de Informação em língua portuguesa, para que fosse realizada leitura de todos os resumos com artigos referentes à temática mediação. Com inspiração na cientometria, e procedimento já realizado com sucesso em trabalhos como os de Piovezan e Cardoso (2015) para avaliação de uma área de investigação científica, a análise de conteúdo de Bardin (1988) foi empregada para se classificar a abordagem de mediação predominante presentes nos resumos recuperados. Os resultados deste trabalho analítico são apresentados na quarta seção deste artigo. Logo em seguida, são apontadas as considerações finais sobre a abordagem da mediação nas áreas estudadas.

\section{O CAMPO DAS MEDIAÇÕES NA CIÊNCIA DA INFORMAÇÃO}

$\mathrm{Na}$ dimensão da informação como processo, que evoca, necessariamente, a compreensão dos fenômenos sociais e culturais fundados na ação de informar (ARAÚJO, 2016), tem emergido a abordagem da mediação como campo específico de estudo na Ciência da Informação. A circulação e apropriação de mensagens nos processos comunicativos, bem como na instituição da memória, são fenômenos info-comunicacionais (MARTELETO, 2010).

No que diz respeito à construção social da realidade, ou seja, da constituição da cultura humana, as mediações são "as conexões que se estabelecem entre as ações sociais e as motivações (individuais/coletivas) (ALMEIDA, 2007, online)", destacando o agente humano (mediador) dos processos sociais. "Mediar é, nesse sentido, vincular ao mundo, é ação de construção de identidades culturais" (PERROTI; PIERUCCINI, 2014, p. 16). "Mediar é ato 


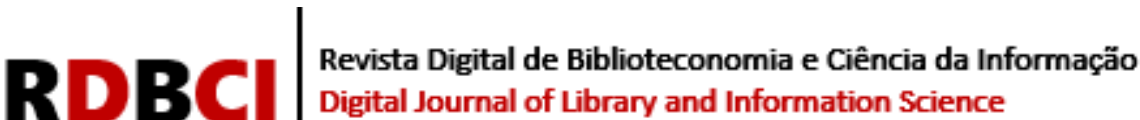

autônomo e afirmativo de criação. Do mundo e de sentidos para ele" (PERROTI; PIERUCCINI, 2014, p. 19).

Perroti e Pieruccini (2014) esclarecem que a mediação apresenta uma dupla direção: uma das relações interpessoais-horizontais - de ordem micro, e outra das relações societárias-verticais, da ordem do macro.

\subsection{Mediação horizontal}

$\mathrm{O}$ ato mediador, em seu eixo horizontal, é sempre caracterizado pela interação de agentes humanos (o mediador e o mediado em dimensões individuais e coletivas) dotados de intencionalidade e reciprocidade, transcendência e significado (VARELA, 2007). O mediador exerceria ação consciente com vistas a modificar o estado atual (como o estado de conhecimento ou mobilização de recursos) do mediado, de maneira a modificar o seu sistema de referências para a vida (transcendência e significado). Diferente do papel do mediador (fundado na alteridade e reciprocidade, que exercem papel transformador da realidade), situa-se o trabalho do intermediário (previsível e calculado), o qual é associado ao transporte de mensagens ou significados, sem fundamento em trocas comunicativas autênticas, cumprindo função de reprodução do que já existe (LATOUR, 2012).

Em um nível micro, situacional, horizontal, o ato mediador e também o ato intermediador se dão pela expressão na linguagem, por sistemas de signos compartilhados entre os atores envolvidos. "Por esta natureza mediadora primeira da linguagem, entende-se que o emissor de qualquer mensagem codificada assume papel determinante no processo de semiose do receptor" (ROCHA, 2016, p. 70). Silva (2009) explicita que um dos tipos de mediação é a da língua. Aqui, apresenta-se a faceta sociocognitiva da mediação, constituinte e subjacente de qualquer processo mediador: a mediação é vista como um processo intencional de um agente com vistas a modificar o estado mental de um outro, levando em conta seus processos cognitivos e suas possibilidades de entendimento da mensagem no âmbito da cultura (dos limites de compreensão do destinatário), por intermédio da linguagem. A mediação como possibilidade de direcionamento do processo de semiose está presente na avaliação de diversas atividades realizadas no âmbito da comunicação de massa, e de diversas instituições, sejam culturais ou não. Essa seria a mediação mediática (DAVALLON, 2007), ou mediação implícita (ALMEIDA JÚNIOR, 2009), em que usualmente profissionais atuantes nos meios de comunicação e nas instituições procuram emitir mensagens para provocar certas leituras e interações direcionadas dos seus usuários e públicos. No caso das bibliotecas e instituições arquivísticas, essas atividades são conceituadas de mediação implícita - trabalho no "âmbito da

identificação, seleção, classificação e processamento informacional" da "informação-ainda-não-latente" (FERREIRA; ALMEIDA JÚNIOR, 2013, p. 163) ou protoinformação.

Ainda na dimensão horizontal, os processos cognitivos de apropriação de mensagens e o trabalho de profissionais para realização de traduções é essencial, o que ressalta a dimensão sociocognitiva do conceito de mediação. $O$ trabalho de profissionais da informação e da comunicação é entendido como um trabalho de mediação na medida em que esses profissionais fazem circular mensagens que servem de ponte entre o produtor e seu receptor. Davallon (2007) pontua que o jornalista, por exemplo, invariavelmente exerce esse papel de ponte: ao veicular uma fala de alguém em um jornal, ele está decodificando aquela mensagem para um público amplo, de maneira a ser compreendida em seu sentido cognitivo. Entre aquele que diz (um) e o outro que recebe (dois) a mensagem, o mediador é um terceiro, e seu ato jamais é neutro. Também as instituições culturais, como museus, operam desta forma: entre os curadores e 


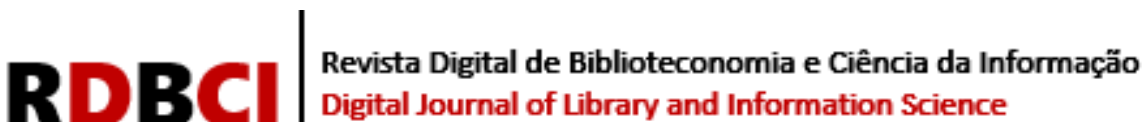

enunciadores e os públicos, atua um terceiro, o designer de exposição, que deverá ter o cuidado de antecipar possíveis interpretações do público. Essa forma de mediação mediática requer que o mediador domine a linguagem, como a linguagem jornalística (caso do jornalista), ou as linguagens documentárias (no caso dos profissionais da documentação e biblioteconomia), ou as linguagens expositivas (no caso dos profissionais museólogos) ou os procedimentos de descrição da documentação arquivística (ROCHA, 2016) para realizar um trabalho que seja entendido por seus públicos e usuários. Seria a ponte entre a linguagem especializada do profissional e seus públicos, com algumas dificuldades maiores para alguns do que para outros. Mas a natureza da ponte (se vai se tratar de uma ponte de madeira, uma pinguela, ou uma estrutura metálica) e os materiais à disposição para se fazê-la, determinam parcialmente as possibilidades de mediação. Os meios técnicos impõem limitações para o uso de uma linguagem que seja natural, produzindo efeitos próprios, conhecidos pelo conceito de mediatização - codeterminação da técnica na produção dos fenômenos comunicacionais, já que a técnica (como as interfaces computadorizadas, por exemplo), jamais é neutra, ela cumpre papel de determinar, parcialmente, as possibilidades comunicativas entre os profissionais que a utilizam e seus usuários e públicos.

Neste aspecto, é importante pontuar que o agente humano tanto é visto como um indivíduo (em interações cotidianas íntimas) ou como um agente a serviço de algum propósito institucional, em algum papel social. Complementando a visão dos agentes como sujeitos individuais ou representantes de alguma instituição, também se deve levar em conta os atores institucionais - como as organizações, entidades públicas ou privadas, no nível meso (nem micro, nem macro) nos processos de mediação. Desta forma, um jornalista é um agente individual, mas que atua de maneira a colocar a fala institucional em um veículo de comunicação, que é um ator em si. O veículo de comunicação é um ator institucional que se apresenta na fala do jornalista. Mas daí já é necessário pensar no eixo de mediação vertical, em que a amplitude das relações institucionais é considerada.

\subsection{Mediação vertical}

O jogo dos atos mediadores e intermediadores realizados pelos atores sociais indivíduos, organizações, movimentos sociais e culturais, atuadores - deve ser levado em conta em um quadro de referência macrossocial. É nessa direção que se torna importante pensar na obra de Martin-Barbero (2013) (ver FIG.1). Para ele, as mediações são tidas como "tecido de processos e materialidades da comunicação em um ambiente social e cultural" (LOPES, 2014, p. 72). O social não está dado, mas é constantemente construído em trocas comunicativas cada vez mais mediatizadas: cada vez mais a realidade não é construída por relações interpessoais face a face, mas por relações constituídas por (inter)médio dos meios de comunicação de massa e por redes telemáticas. Há profunda transformação na forma com que os processos sociais políticos, culturais, produtivos - são construídos.

Além da dimensão de mediação intrínseca da comunicação na configuração da sociedade, o modelo de Martin-Barbero (2013), ainda considera: a) que o consumo cultural é construído em relações de negociação de sentidos entre os sujeitos (competências de consumo) e as matrizes culturais mediadas pela socialidade; b) que a produção cultural (lógica da produção) leva em conta as matrizes culturais pela mediação da institucionalidade; c) que a lógica da produção e os formatos industriais seguem uma ordem técnica (mediação da tecnicidade) e, d) que o consumo, na relação com a oferta social dos formatos culturais, é mediado pela ritualidade. 


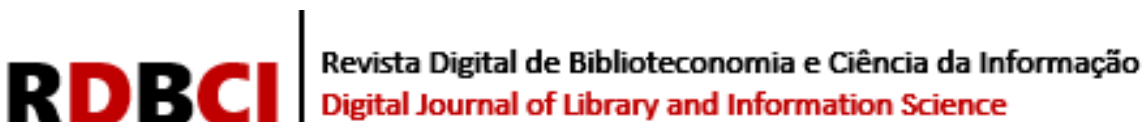

Figura 1. Mapa metodológico das mediações

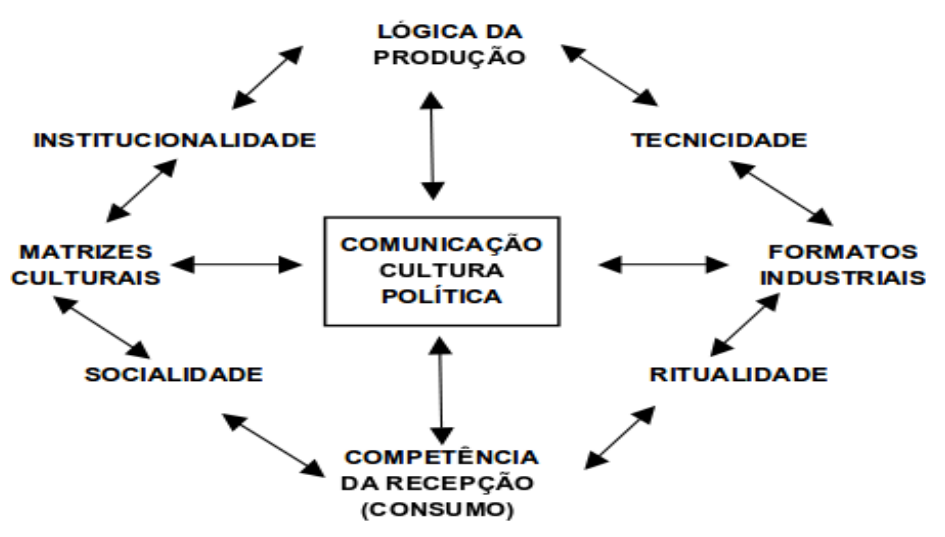

Fonte: LOPES, 2014, p. 71

O modelo de Barbero (2013) permite compreender a comunicação como mediadora de processos culturais. A organização de manifestações culturais, por exemplo, evidencia a existência de uma matriz cultural que se articula com o mundo do cotidiano, nas relações de socialidade dos membros de grupos (e aqui é possível que existam mediadores culturais, animadores culturais e educadores) e ações de mediação que mantenham a espontaneidade ou a vida cultural dos grupos. Uma vez que tais manifestações são apreendidas pelas atividades mediadoras dos meios de comunicação e outras instituições culturais (como os museus), a ação da institucionalidade (as ações de musealização; ou a instituição de políticas de formação de acervos e fundos em bibliotecas e arquivos; ou a institucionalização de movimentos sociais organizados diversos, por exemplo) requer a intencionalidade de mediadores no campo social e da cultura (como membros porta-vozes dos grupos e das instituições). A mediação da informação, por esse quadro conceitual, se associa aos processos de mediação documentária (quando se institui o documento diante dos processos sociais, portanto associada à institucionalidade) que ocorre tanto em dimensões implícitas da prática documentária quanto explícitas (ORTEGA, 2015; ALMEIDA JÚNIOR, 2009).

Tanto Teixeira Coelho (1989) quanto Perrotti e Pieruccini (2008) visualizam três vias para esse trabalho mediador das instituições de cultura, partindo das matrizes culturais para os regimes de institucionalidade: 1) a via da preservação e conservação cultural, em que as instituições são depositárias de objetos da cultura material ou promovem ações de animação cultural para conservar aspectos da cultura imaterial, por exemplo; 2) pela via da difusão cultural, em que a ação educativa pode cumprir papel essencial, possibilitando que manifestações culturais sejam assimiladas e perpetuadas no tecido cultural, sem envolver processos de criação do novo; 3) pela via da facilitação ao processo de apropriação e criação cultural (fomento ao protagonismo cultural), sem antecipação de qualquer resultado. Torna-se clara a diferença entre o difusor e o mediador, ao se associar as visões de Teixeira Coelho (1989) e Perrotti e Pieruccini (2014):

O horizonte de expectativas do [difusor...] é a assimilação das mensagens pelo "receptor", tomado como categoria isolada e particular. O do segundo [mediador], é a cultura, ou seja, a esfera pública da criação de sentidos. Nessa perspectiva, a mediação não é apenas operação: é ação deontológica sobre a cultura e o mundo, modo especial de produção legitimada por imperativo ético-ontológico que ultrapassa e se distingue do imperativo da funcionalidade que sustenta o tecnicismo (PERROTI; PIERUCCINI, 2014, p.13). 


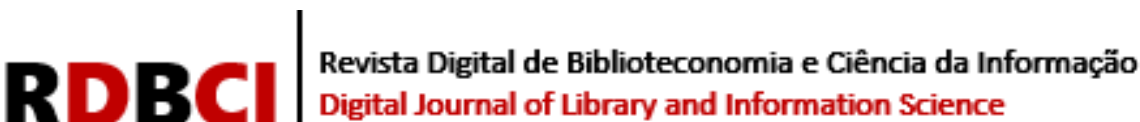

Por outro lado, no referencial de Martin-Barbero (2013) (FIG.1), também se vislumbra a compreensão da lógica das possibilidades técnicas de constituição de manifestações culturais em formato industrial ou não (tecnicidade), que, na relação com o consumo requer sua adequação aos hábitos pessoais e coletivos (ritualidade). Sempre se corre o risco da apropriação indébita de manifestações culturais em suas matrizes culturais, com todo o seu sentido no cotidiano dos grupos produtores (em suas práticas sociais, na socialidade) segundo a lógica produtiva dos meios de comunicação com sua linguagem própria, com suas restrições em seus formatos industriais.

Algumas instituições têm papel protagonista na produção cultural, por se constituírem em instituições da indústria cultural, conforme seus formatos industriais (como os meios de comunicação de massa), outras não participam da lógica produtiva, não são indústrias culturais (como as bibliotecas e as instituições arquivísticas). Os museus ocupam, nesse espaço, uma posição importante na produção cultural e são consideradas como mídia em si mesmos, diferentemente das instituições arquivísticas e bibliotecas, o que lhes confere especificidades em suas práticas de mediação em relação às outras instituições. Essa é uma hipótese importante da pesquisa que se delineou e que será mais bem explorada na etapa de análise de dados das publicações desse estudo. Tanto Lousada (2016) quanto Ortega (2010) e Martins (2013) concordarão que os processos envolvidos no ciclo documentário - produção do documento, organização e disseminação - são todos marcados pelas instituições biblioteca, arquivo e museu. Em outras palavras, há mediação em todo o ciclo documentário (mediação implícita na produção e organização do documento que pode e deve levar em conta os processos sociais e culturais que deram origem a ele; mediação explícita na disseminação), mas os processos de origem estão atrelados às ordens já estabelecidas pelas instituições na sociedade (como instituições arquivísticas e biblioteca) - em outras palavras, as instituições biblioteca e arquivo não atuam, originalmente, como fomentadoras de manifestações culturais das coletividades. A natureza dos documentos difere o papel da instituição (se biblioteca, arquivo ou museu) no âmbito da cultura. As instituições arquivísticas, por serem depositárias de documentos decorrentes de atividades administrativas, estão menos associadas às dinâmicas de produção cultural, exceto quando se propõe a editar materiais bibliográficos concernentes aos seus fundos e coleções. Raciocínio análogo vale para aquelas bibliotecas que não têm como uma de suas formas de atuação o trabalho de edição de obras, mesmo quando assumem o papel de mediação da leitura. Já o museu é importante ator na produção cultural, tendo sido considerado mídia (TUCHERMAN; CAVALCANTI, 2010).

As condições de produção cultural presentes nos regimes de sociabilidade não têm sido consideradas como objeto da mediação documentária de instituições como bibliotecas e instituições arquivísticas, embora possam ser tomadas como mediação informacional em um conceito ampliado de informação como mecanismo mediador da cultura (MARTINS, 2010). As condições de ritualidade podem ser expressas na construção das relações do consumo cultural, especialmente nos museus (inseridos em uma dinâmica cultural associada a processos de distinção social, BOURDIEU; DARBEL, 2003).

Para além do modelo de Martin-Barbero (2013) ainda seria preciso considerar as mediações da leitura (talvez presente nos regimes de institucionalidade, nas ações intencionais das instituições junto aos grupos que podem produzir cultura/matrizes culturais/mundo da vida e também nos espaços de sociabilidade), a mediação da aprendizagem (também podendo estar presente nas dimensões da sociabilidade e da institucionalidade em espaços como os escolares e nas instituições de memória e cultura) e a mediação sociocognitiva supramencionada (dos processos mentais envolvidos na recepção e consumo). 


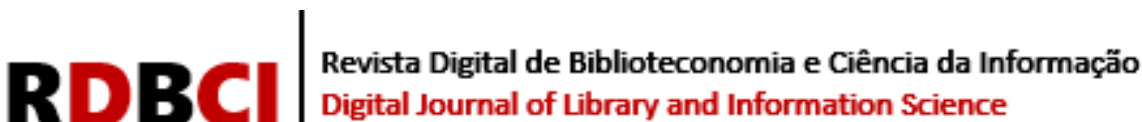

\begin{abstract}
Identificação, seleção, produção de registros, ordenação, preservação, exposição de todo e qualquer objeto são atividades documentárias no sentido de que constituem de modo articulado entre si - ações de mediação a partir das quais se dá a transformação do objeto em documento. Estas ações formam camadas de significação sobre o objeto, cada qual ressignificando a anterior, em um movimento de produção de mensagens a um público. $\mathrm{O}$ documento é esse objeto ressignificado e a noção de documento é dependente de uma elaboração teórico-metodológica dessas ações (ORTEGA, 2015, p.2).
\end{abstract}

$\mathrm{Na}$ discussão sobre as mediações, no campo da CI, diversas formas de mediação têm sido conceituadas, com destaque para a mediação documentária e a mediação cultural. Essas duas dimensões da mediação são interrelacionadas na medida em que se considera que o documento, na mediação documentária, é produto de uma cultura - pode ser um produto cultural de um grupo organizado que se queira preservar (que requerem ações de musealização), pode ser um documento de uma empresa pública que socialmente se convencionou preservar (que requer ações de gestão de documentos arquivísticos), pode ser uma obra literária ou acadêmica necessária para disseminação e produção de conhecimento (que requer ações de formação de coleções e processamento técnico em bibliotecas). Embora se reconheça que há especificidades, por equipamento informacional e cultural, em todas as fases do processo de documentação - produção, organização e disseminação - há medição institucional, realizada por profissionais.

O dispositivo info-comunicacional propõe, por meio de uma forma de enunciação, um lugar de estruturação de conhecimentos e de recepção e apreensão da informação. As dimensões sociais e técnicas do dispositivo se constituem por atores, técnicas e objetos materiais em interação permanente e em um contexto definido (ORTEGA, 2015, p. 10).

No processo de produção, destaca-se a mediação institucional, que tem características de mediação mediática e implícita (em que o público/o usuário é tido como uma referência para construção da mensagem de forma a aproximar o universo dos produtores do documento e produtores culturais, o contato com o usuário/público não é dialógico). Também é possível imaginar um processo de produção dialógico, em que o público/o usuário faça parte da produção das mensagens, da criação do documento, tendo-se aí a mediação cultural, que é explícita por natureza. Já no processo de organização, usualmente a instituição ordena, categoriza os documentos conforme seus processos de mediação implícita, também orientados pelas técnicas e linguagens documentárias. O processo de disseminação pode ser conduzido como forma de mediação da instituição para que o público/usuário usufrua dos produtos/documentos, e tem características de mediação explícita (realizada diretamente junto aos públicos/usuários) conduzida por ações educativas - tais como atendimento ao usuário, visitas guiadas - e por serviços de referência.

Já a mediação informacional é tida como sinônima de mediação documentária para Ortega (2015), apesar de que documento e informação não são sinônimos. Considera-se que o documento se difere da informação e esta requer também trabalhos de mediação associados ao seu ciclo (produção, organização, disseminação e uso). Para Ortega (2015, p. 3) "objetos tornam-se documentos por serem abordados informativamente".

O documento é o produto de atividades sistemicamente realizadas com o fim de apropriação da informação por um público. Dito de outro modo, documentos são informações selecionadas e organizadas materialmente em um sistema, cujas significações objetivam, por sua vez, orientar o processo de significação pelo público (ORTEGA, 2015, p. 3). 


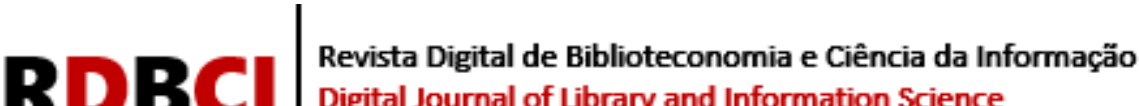 \\ Digital Journal of Library and Information Science
}

Em relação aos documentos, Ortega (2015) discute, informada pelo pensamento de Meyriat, a diferença entre o documento por intenção e o documento por atribuição.

\begin{abstract}
Documento por intenção é denominação permanente quanto ao objeto a que se refere, já que se trata de característica relativa a sua produção. Além disso, pode-se dizer que a informação é mais evidente no documento por intenção, como no caso dos textos escritos científicos que se inscrevem em fluxos de comunicação científica. Considerando o documento como um objeto que significa, podemos falar em ao menos três níveis de significação: a produção dos documentos com intenção informativa; as propostas de significação sobre aqueles documentos a um público; e a significação que ocorre no processo de apropriação da informação realizada pelo usuário. O segundo nível de significação é de responsabilidade do profissional documentalista e de outros que atuam material e simbolicamente em torno do documento e o terceiro nível é o objetivo e motivação dos anteriores. No entanto, se as atividades documentárias são ações de mediação realizadas com intenção informativa sobre objetos, esses mesmos objetos podem ou não ser produzidos com intenção informativa. Para que seja propriamente um documento, o objeto depende de ser usado como tal (documento por atribuição) e não somente proposto como tal (documento por intenção), a despeito de os dois casos envolverem processos interpretativos. Assim, se o primeiro nível de significação não é obrigatório, nem o segundo precisa existir, apenas o nível de significação realizado pelo usuário está em questão para a existência do documento, portanto, para sua definição (ORTEGA, 2015, p. 10).
\end{abstract}

No entanto, há diversas atividades pouco sistematizadas de organização de objetos por instituições. No caso das redes de comunicação e das trocas comunicativas cotidianas, talvez não exatamente aconteça a produção de documento e o trabalho mediador para criá-lo, mas, a mediação comunicativa, a mediação informacional em sentido diferente do proposto por Ortega (2015), que situa mediação informacional e documentária como sinônimas. Silva (2009) considera outras formas de mediação pós-custodiais para a fluidez crescente dos processos sociais de produção de informação fora dos arranjos institucionais já estabelecidos, mas para os quais se poderia atribuir caráter documentário.

Embora não com esses termos, a mediação pós-custodial pode ser relacionada à mediação extrainstitucional. As fronteiras institucionais (das bibliotecas, instituições arquivísticas, museus, centros de cultura, centros de documentação e memória) são, no limite, revistas. Para estes casos, da mediação informacional, a quantidade e qualidade de atores institucionais são bastante difusas (ver quadro 1). Outra discussão importante é o processo de desmediação, o qual poderia ser entendido como mudança dos regimes de institucionalidade na sociedade. A informação, nas redes, passaria por um processo de autovalorização e regulação pelos seus públicos.

$\mathrm{Na}$ mesma direção, seria importante, ainda pensando no âmbito pós-custodial e extrainstitucional, problematizar o papel protagonista que as instituições podem ter na formulação de políticas públicas de acesso à informação e cultura.

A mediação extra-institucional, conforme vislumbrada por Silva (2009), diria respeito à ultrapassagem das fronteiras institucionais para os processos do ciclo informacional e também do ciclo documentário. Ao se evocar Foucault e Sartre no que diz respeito ao conceito de instituição (HONORATO, 2015), enquanto relações cristalizadas na ordem social:

\footnotetext{
uma mediação extrainstitucional tem menos interesse em corresponder às 'características e necessidades' (identitárias) dos visitantes, de maneira semelhante à relação das empresas com seus clientes, do que em potencializar contrapúblicos, que se manifestam, sem identidade, numa divisão de cada um consigo mesmo, numa quebra de ligação com as expectativas de sua inserção em determinados ritos e/ou processos de socialização (HONORATO, 2015, p. 219).
} 


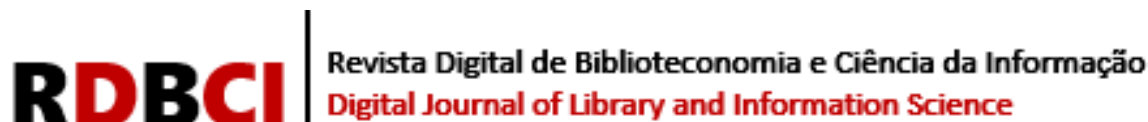

Nota-se que as instituições biblioteca, arquivo e museu têm questionado seus limites de atuação (talvez se reestruturando) para dar conta dos processos cotidianos que lhes escapam. Algumas delas já tem se colocado como atores em mediações extra-institucionais (além dos limites clássicos de sua atuação). Não é de se espantar que a área de Sistemas de Informação não apresente a discussão sobre as mediações. A lógica das redes tenderia para a fluidez e descentralização diferente das lógicas das instituições informacionais e culturais tradicionais.

Quadro 1. Mediação pós-custodial

\begin{tabular}{|c|l|}
\hline $\begin{array}{c}\text { Tipos de mediação } \\
\text { pós-custodial }\end{array}$ & \multicolumn{1}{c|}{ Caracterização } \\
\hline Institucional & $\begin{array}{l}\text { Enquadra-se dentro das tradicionais instituições culturais, como são as } \\
\text { Bibliotecas e os Arquivos, é exercida pelos mediadores especializados, como } \\
\text { são os bibliotecários e os arquivistas, mas, ao mesmo tempo, é partilhada com } \\
\text { informáticos e designers de informação, de quem depende a feitura do website } \\
\text { através do qual são disponibilizados os acervos em depósito. }\end{array}$ \\
\hline Distribuída e/ou partilhada & $\begin{array}{l}\text { Ocorre em certos tipos de serviço e media digitais, como websites e blogs, } \\
\text { pertencentes a entidades coletivas e a indivíduos, em que há o(s) mediador (es) } \\
\text { que localiza(m), digitaliza(m), seleciona(m) e disponibiliza(m) conteúdos, há o } \\
\text { designer e a empresa que vendem ou fornecem de forma livre a aplicação e há } \\
\text { aderentes ao serviço que são convidados a intervir ativamente com conteúdos e } \\
\text { comentários. }\end{array}$ \\
\hline Cumulativa & $\begin{array}{l}\text { À medida que se inovam e expandem mais as possibilidades tecnológicas } \\
\text { (novas soluções e produtos) o papel do "prossumidor" (produtor e usuário) } \\
\text { cresce enormemente, desenvolvendo um tipo de mediação cumulativa que pode } \\
\text { abranger a de design e de programador, e que produz efeitos e é condicionada } \\
\text { através da ativa participação em comunidades que agregam interagentes } \\
\text { idênticos ou parecidos. }\end{array}$ \\
\hline
\end{tabular}

Fonte: Adaptado de SILVA, 2009, p. 31.

\subsection{Mediações - uma proposta de síntese}

Decerto que a discussão que aqui se colocou sobre as mediações horizontal e vertical dão uma ideia do papel articulado destas duas formas de mediação que dizem respeito, respectivamente, ao papel da figura do mediador (profissional atuante nas instituições junto aos públicos) e das instituições na ordem social, respectivamente. Destaca-se que as atividades mediadoras estão circunscritas nas ordens institucionais, que, para o caso dos museus é bem sumarizada por Honorato (2015, p. 219):

Certamente, essa condição institucional da mediação está associada a uma variedade de questões: da identidade profissional do mediador (invariavelmente reduzida à prestação de serviços, e por extensão, à precariedade, provisoriedade e vulnerabilidade) às concepções de públicos (invariavelmente apriorísticas, sistêmicas e desistorizadas, limitadas a empirias totalizadas pelas categorias público espontâneo, público agendado e não-público, destituídas de qualquer imaginário politicossocial) (HONORATO, 2015, p. 219).

Em relação aos conceitos apresentados por Martin-Barbero (2013) em seu mapa das mediações (FIG 1), e a discussão sobre os processos de mediação documentária e mediação cultural, é possível afirmar que os processos de mediação são multifacetados e que o conceito de mediação é amplo. A figura 2 e o quadro 2 sumarizam parte da discussão sobre eles.

A figura 2, com uma grande profusão de elementos, ilustra a complexidade de se realizar uma síntese dos estudos sobre mediação. O texto em roxo traz alguns conceitos de 


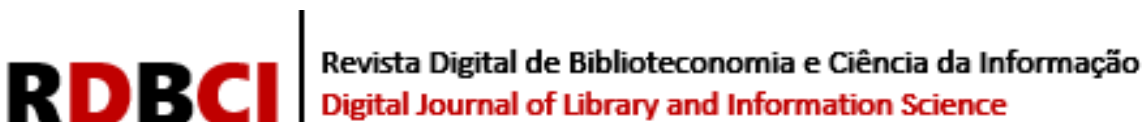

Martin-Barbero (2013) sobre as matrizes culturais e regimes culturais do mundo da vida que são trabalhados em grupo e por mediadores culturais em processos de mediação cultural, os quais tanto podem levar à criação de produtos no âmbito das instituições (como a processos de musealização, por exemplo, que envolvem, também, processos de mediação documentária), ou a transformações societárias maiores nos próprios grupos e outras instituições. Também é possível visualizar, na imagem, o eixo horizontal das mediações, como no caso do auxílio do profissional bibliotecário ao seu usuário, por exemplo, e também as formas de mediação implícita e explícita, em cor bege. Em negrito, preto, destacam-se os processos situacionais (eixo horizontal), e os processos de mediação verticais tanto institucionais quanto macrossociais. O consumo cultural, os processos de leitura, visitas a museus, entre outros aspectos da relação das pessoas com as instituições e meios de informação, são representados por bonecos de palito e setas unidirecionais à esquerda. Privilegiou-se as setas unidirecionais pelo fato de a maioria das relações de consumo cultural não ser dialógica.

Figura 2. uma síntese em imagem das múltiplas facetas da mediação

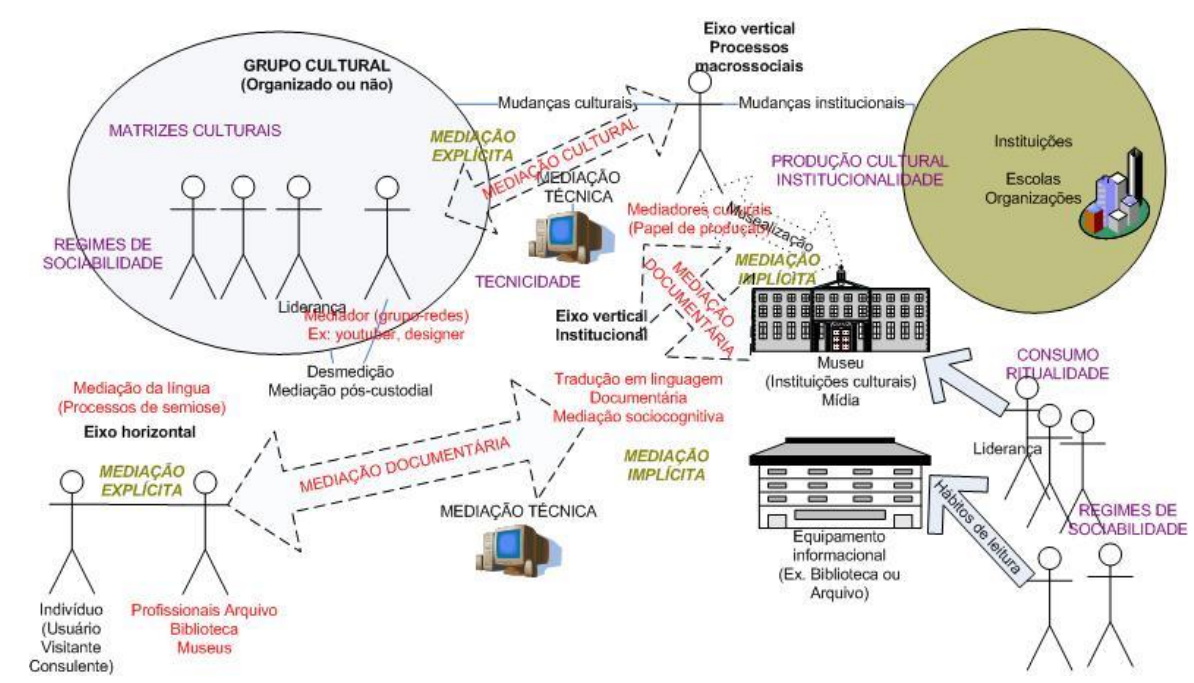

Fonte: Da autora.

No quadro 2, nota-se que há dois grandes sentidos gerais atribuídos ao termo: de mediação e de mediatização, o primeiro referente aos processos de ação de um terceiro no ato comunicativo, o segundo, referente aos processos sociais mediados pela técnica. No que diz respeito às mediações horizontais e verticais, destaca-se a variedade dos processos mediadores horizontais (mediações em interações normalmente sincrônicas relativas a processos de aprendizagem e mediação de leitura, serviços de referência) e verticais (relativos às atuações institucionais na ordem social e cultural, tomadas de um quadro mais amplo). Tanto uns como outros conjugam processos de mediação implícita e explícita.

Quadro 2. Síntese dos processos de mediação

\begin{tabular}{|l|l|l|}
\hline & $\begin{array}{l}\text { Mediação (sentido geral): } \\
\text { Ação transformadora entre sujeitos. Requer } \\
\text { sujeito(s) mediador(es) e sujeito(s) mediado(s), } \\
\text { relações de reciprocidade, partilha. É diferente da } \\
\text { intermediação, que não prevê partilha, que serve à } \\
\text { reprodução do que está dado. }\end{array}$ & $\begin{array}{l}\text { Mediatização (sentido geral): Processo } \\
\text { resultante da ação do meio técnico } \\
\text { presente na ação mediadora. }\end{array}$ \\
\hline Processos & Mediação cultural: a ação mediadora envolve a a & Mediatização da cultura e dos processos \\
\hline
\end{tabular}




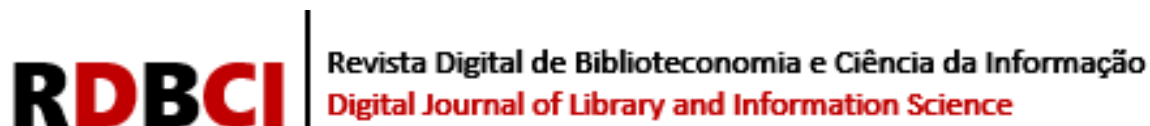

\begin{tabular}{|c|c|c|}
\hline \multirow[t]{2}{*}{$\begin{array}{l}\text { macrossociais } \\
\text { Mediação no } \\
\text { eixo vertical }\end{array}$} & $\begin{array}{l}\text { compreensão dos processos de produção cultural e o } \\
\text { conceito de cultura. O agente mediador poderá ser } \\
\text { um fabricador, animador ou facilitador dos processos } \\
\text { de criação cultural. }\end{array}$ & $\begin{array}{l}\text { societários. Produção cultural vinculada } \\
\text { a processos técnicos e societários em } \\
\text { lógica que pode ser massificada ou fruto } \\
\text { de processos descentralizados em formas } \\
\text { reticulares da cibercultura. }\end{array}$ \\
\hline & $\begin{array}{l}\text { Mediação social: mediação que diz respeito à } \\
\text { formação e criação de grupos, de movimentos } \\
\text { coletivos. }\end{array}$ & \\
\hline $\begin{array}{l}\text { Processos } \\
\text { institucionais } \\
\text { Mediações no } \\
\text { eixo vertical } \\
\text { (na } \quad \text { ordem } \\
\text { social) }\end{array}$ & 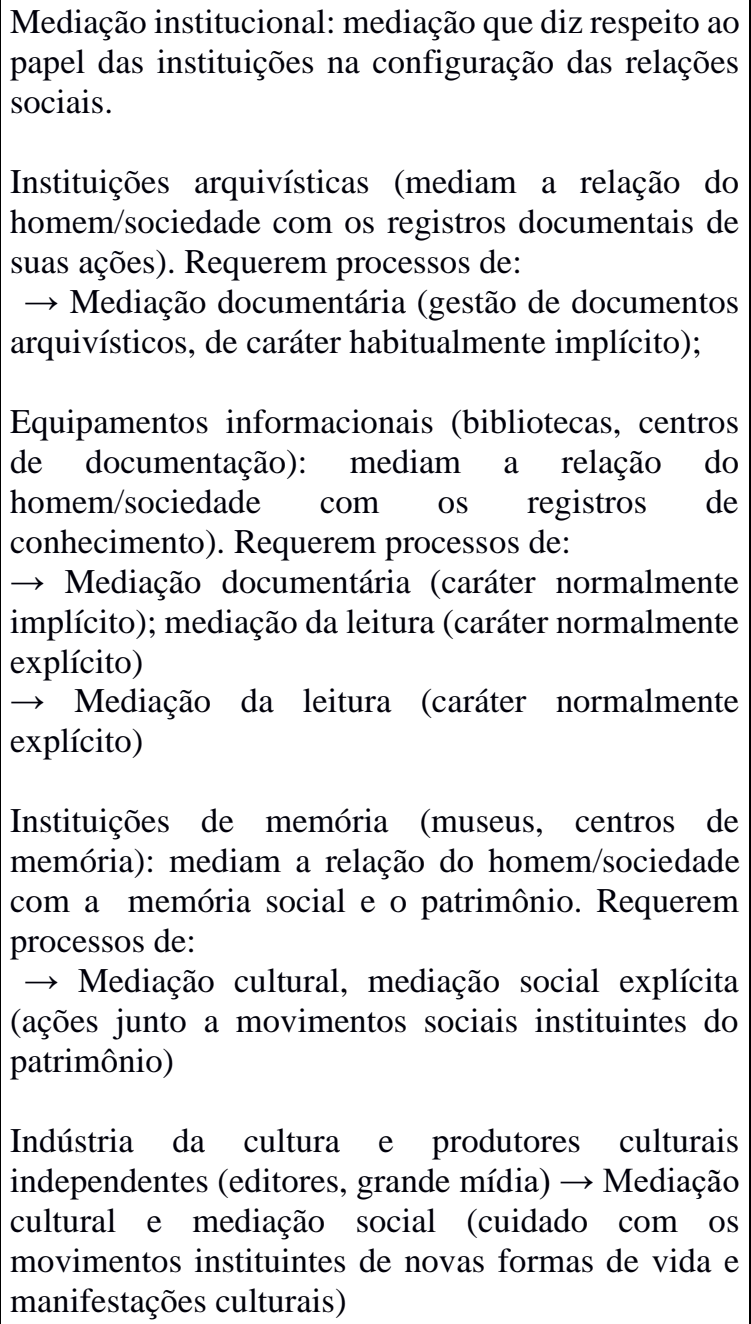 & $\begin{array}{l}\text { Mediação extrainstitucional (relacionada } \\
\text { fortemente ao processo de mediatização) } \\
\text { Fora das organizações já instituídas } \rightarrow \\
\text { Mediação distribuída, mediação } \\
\text { cumulativa, desmediação } \\
\text { Movimento centrífugo das instituições } \\
\rightarrow \text { Mediação pós-custodial }\end{array}$ \\
\hline $\begin{array}{l}\text { Situação } \\
\text { interativa } \\
\text { Mediação no } \\
\text { eixo horizontal }\end{array}$ & $\begin{array}{l}\text { Mediação sociocognitiva: processo em que ocorre a } \\
\text { partilha de significados entre mediador e mediado } \\
\text { por meio de linguagem compartilhada (linguagem } \\
\text { esta que precisa ser socialmente partilhada e } \\
\text { cognitivamente decodificada, por processos de } \\
\text { semiose). } \\
\text { Requer processos de mediação da aprendizagem em } \\
\text { espaços formais e não formais, conforme entendidos } \\
\text { por Gohn (2006): ação mediadora que acontece em } \\
\text { cenários institucionalizados (educação formal - } \\
\text { escolas, educação não formal- espaços } \\
\text { institucionalizados, como museus) ou em cenários } \\
\text { não formalizados (educação informal). O mediado é } \\
\text { aquele que aprende, enquanto o mediador quase } \\
\text { sempre assume a postura de um "professor". }\end{array}$ & $\begin{array}{l}\text { Mediação técnica: processo que toma a } \\
\text { ferramenta técnica utilizada em papel de } \\
\text { agente mediador, como um ator na } \\
\text { relação. Exemplo: ao interagir com um } \\
\text { aplicativo de banco, o aplicativo se torna } \\
\text { um agente mediador do usuário com } \\
\text { alguma instituição bancária; ao interagir } \\
\text { com um SRI, a interface do sistema ajuda } \\
\text { a moldar as questões do usuário para } \\
\text { localização de referências; ao interagir } \\
\text { com um guia virtual em um museu, } \\
\text { também há a ação da interface do seu } \\
\text { programa ajudando a configurar a relação } \\
\text { do usuário com as obras expostas. }\end{array}$ \\
\hline
\end{tabular}




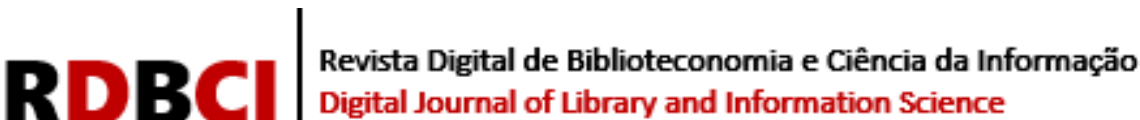

Normalmente acontece por processos de mediação

explícita.

Fonte: organizado pela autora.

O quadro síntese não esgota as possibilidades de interpretação e tratamento da temática:

\begin{abstract}
a ideia de mediação acaba por compreender aspectos tão distintos entre si, que vão das velhas concepções de "atendimento ao usuário" à atividade de um agente cultural em uma dada instituição - museu, biblioteca, arquivo, centro cultural -; à construção de produtos destinados a introduzir o público num determinado universo de informações e vivências (arte,educação, ecologia, por exemplo); à elaboração de políticas de capacitação ou de acesso às tecnologias de informação e comunicação etc. Desse modo, uma definição consensual de mediação parece impraticável: sempre contextualizada, torna-se um conceito plástico que estende suas fronteiras para dar conta de realidades muito diferentes entre si (LOUSADA, 2016, p. 123).
\end{abstract}

Para dar conta do conceito e de suas implicações, a próxima seção apresentará resultado de um processo de análise de artigos recuperados com a temática da mediação, para se ter uma ideia a quais realidades tem se referido a temática, na Ciência da Informação e áreas correlatas.

\section{METODOLOGIA}

O propósito do estudo foi identificar de que maneira o conceito de mediação tem sido abordado na área de Ciência da Informação e Biblioteconomia, Arquivologia, Museologia e Sistemas de Informação, tendo como categorias de classificação aquelas apresentadas no quadro de síntese 2 - processos verticais macrossociais e institucionais da mediação, processos horizontais. Os periódicos foram escolhidos por meio de consulta à Plataforma Sucupira que atendiam ao critério de boa classificação (estratos A1 até B1) em língua portuguesa, nas áreas de Comunicação e Informação para o triênio 2013-2016. Porém, com tal critério, algumas das áreas seriam subrepresentadas, como as áreas de Arquivologia e Sistemas de Informação, a última sem revistas em tais estratos. Para áreas subrepresentadas em relação à CI e Biblioteconomia, com poucas revistas nos estratos A1-B1 na área de Comunicação e Informação (como Arquivologia, Sistemas de Informação e Museologia), também os estratos B2 e B3 foram considerados. Algumas revistas, embora classificadas nos estratos A1-B3 com tais critérios foram descartadas por não estarem atualizadas, como foi o caso da revista DataGramaZero, ou por não se referirem especificamente às áreas eleitas para o estudo, excluindo, portanto as que são específicas da área de Comunicação Social nos seus campos teóricos e práticos. Periódicos em outras línguas, como o espanhol ou inglês, não foram incluídos, devido ao volume já demasiado grande de artigos recuperados em língua portuguesa, o que levou ao desdobramento da pesquisa em outras, uma delas, finalizada e em vias de publicação, diz respeito às abordagens da mediação em periódicos de língua inglesa no campo da Arquivologia.

Selecionadas as revistas, foi realizado trabalho de extração de todos os resumos de artigos que contivessem a palavra "mediacao", "mediações", nos sistemas de recuperação da informação das revistas, publicados no período compreendido entre os anos de 2007 a 2017. Optou-se pela análise dos resumos como uma estratégia para realizar uma avaliação temática panorâmica, a exemplo do trabalho realizado por Piovezan e Cardoso (2015), ao avaliarem o desenvolvimento de uma área de pesquisa, no caso, da área de avaliação psicológica e educacional, por meio de análise de conteúdo de resumos de diversos artigos publicados em 


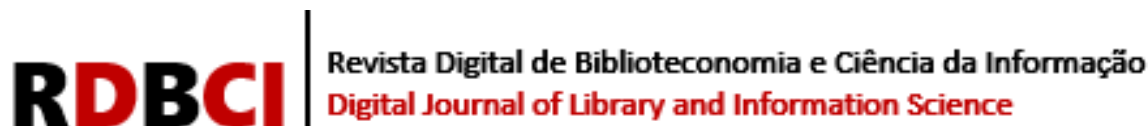

eventos científicos. As autoras explicitam que o trabalho para avaliação do desenvolvimento de uma ciência - metaciência - pode se valer de indicadores de produção científica (como os indicadores de fatores de impacto, relativos à cientometria) e também de análises de discurso e conteúdo de trabalhos científicos produzidos. Tais análises possibilitam mapear o desenvolvimento temático de áreas de estudo, aspecto que convergia inteiramente com os propósitos da pesquisa aqui realizada de mapeamento do campo das mediações. Ao todo, 247 artigos foram recuperados, sendo que dez deles não apresentavam resumos, e outros 20 não versaram sobre mediação diretamente, tendo sido analisados 214 resumos de artigos, sumarizados na tabela 1, por revista e área consultada. Foi criado um formulário no Google Forms para inclusão das categorias analisadas por resumo do artigo, categorias que foram criadas de maneira dedutiva, de acordo com o processo de análise de conteúdo, a partir da revisão bibliográfica realizada e discutida nos tópicos anteriores deste artigo. Posteriormente, os dados alimentados no Google Forms foram exportados e tratados no Microsoft Access para análise.

Tabela 1. Total de resumos de artigos recuperados para análise

\begin{tabular}{|c|c|c|}
\hline Área & Revista & $\begin{array}{c}\text { Total de resumos } \\
\text { analisados }\end{array}$ \\
\hline $\begin{array}{l}\text { Sistemas de } \\
\text { Informação }\end{array}$ & $\begin{array}{l}\text { JISTEM (Journal of Information Systems and Technology } \\
\text { Management) }\end{array}$ & 3 \\
\hline \multirow[b]{2}{*}{ Arquivologia } & Ágora & 4 \\
\hline & Informação Arquivística & 1 \\
\hline \multirow{11}{*}{$\begin{array}{l}\text { Ciência da } \\
\text { Informação e } \\
\text { Biblioteconomia }\end{array}$} & Biblionline & 9 \\
\hline & Ciência da Informação & 15 \\
\hline & Em Questão & 22 \\
\hline & Informação \& Informação & 27 \\
\hline & Informação \& Sociedade & 17 \\
\hline & Perspectivas em Ciência da Informação & 16 \\
\hline & Pesquisa Brasileira em Ciência da Informação e Biblioteconomia & 20 \\
\hline & RBD - Revista Brasileira de Biblioteconomia e Documentação & 11 \\
\hline & RBDCI - Revista Digital Biblioteconomia e Ciência da Informação & 13 \\
\hline & $\begin{array}{l}\text { Revista Ibero-Americana de Ciência da Informação e Tendências da } \\
\text { Pesquisa Brasileira em Ciência da Informação }\end{array}$ & 13 \\
\hline & Transinformação & 7 \\
\hline \multirow{6}{*}{ Museologia } & Anais do Museu Paulista & 5 \\
\hline & Cadernos de Sociomuseologia & 3 \\
\hline & MIDAS & 15 \\
\hline & Museologia e Interdisciplinaridade & 6 \\
\hline & Museologia e Patrimônio & 4 \\
\hline & Revista Museu de Arqueologia e Etnologia & 3 \\
\hline Total & & 214 \\
\hline
\end{tabular}

Fonte: Dados da pesquisa.

Notas: três periódicos foram selecionados na área de Sistemas de Informação, mas apenas um deles levou à recuperação de artigos. Embora o periódico da área de Sistemas esteja com nome em inglês, ele é editado no Brasil e conta com vários artigos em língua portuguesa. A revista MIDAS é editada em Portugal, mas, como apresenta artigos em língua portuguesa, foi considerada no estudo. 


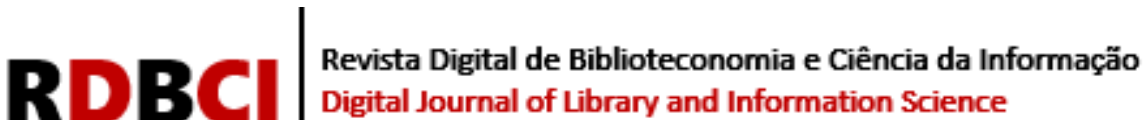

\section{ANÁLISE: A ABORDAGEM DAS MEDIAÇÕES NAS ÁREAS EM FOCO}

Em termos quantitativos e absolutos, nota-se que a temática mediação é mais referenciada nos periódicos da Ciência da Informação e Biblioteconomia (170 resumos), seguida da Museologia (36 resumos), com discussão praticamente inexistente na área de Sistemas de Informação (três resumos). Já na área de Arquivologia, a discussão é tímida (cinco resumos).

Em termos qualitativos, a temática aparece predominantemente presente em artigos de revisão teórica (119 artigos), seguidos de artigos com descrição de estudos de campo ou relatos de experiência (95 artigos). Procurou-se avaliar a presença de perspectivas teóricas e de metodologias de intervenção para mediação em trabalhos empíricos e relatos de experiência. Para cada resumo lido, foi realizada análise de conteúdo para identificar citação de autores e de técnicas de pesquisa utilizadas em relatos de experiência ou estudos empíricos. O sumário da análise dos locais de intervenção e técnicas de pesquisa encontram-se presente no quadro 3, já a apresentação das perspectivas teóricas, no quadro 4.

Quadro 3. Locais e técnicas de pesquisa referenciados em artigos com estudos empíricos e relatos de experiência

\begin{tabular}{|c|c|c|}
\hline Área & $\begin{array}{c}\text { Local de pesquisa/intervenção } \\
\text { (Equipamentos culturais, informacionais, grupos } \\
\text { ou organizações citados) }\end{array}$ & $\begin{array}{l}\text { Técnicas de pesquisa ou } \\
\text { intervenção citadas }\end{array}$ \\
\hline $\begin{array}{l}\text { Ciência da } \\
\text { Informação e } \\
\text { Biblioteconomia }\end{array}$ & $\begin{array}{l}\text { Bibliotecas universitárias (10); grupos culturais, } \\
\text { grupos sociais (8); órgãos governamentais, como } \\
\text { ministério da saúde (8); redes, internet e aplicativos } \\
\text { (8); rede de bibliotecas ou bibliotecas em rede (6); } \\
\text { veículos de imprensa ou cinema (4); bibliotecas (sem } \\
\text { especificação de tipo) (3); organizações para inclusão } \\
\text { digital (3); organizações privadas ou comerciais (3); } \\
\text { laboratórios de pesquisa (2); biblioteca pública ou } \\
\text { biblioteca comunitária (2), universidades; memorial; } \\
\text { patrimônio arqueológico; escola; arquivo. }\end{array}$ & $\begin{array}{l}\text { Entrevistas, observação não } \\
\text { participante, realização de tarefas, } \\
\text { oficinas, questionários, } \\
\text { observação participante, pesquisa } \\
\text { censitária. }\end{array}$ \\
\hline Museologia & $\begin{array}{l}\text { Museus de naturezas diversificadas (histórico, de } \\
\text { ciência (2) e tecnologia, de arte, de Arqueologia), sítio } \\
\text { arqueológico, visitantes, comunidades e grupos } \\
\text { culturais, grupos religiosos, escola, espaço urbano } \\
\text { (geral); patrimônio ambiental; patrimônio cultural; } \\
\text { arquivo. }\end{array}$ & $\begin{array}{l}\text { Observação participante, } \\
\text { entrevistas, histórias orais, } \\
\text { entrevistas narrativas, observação, } \\
\text { rodas de conversa, realização de } \\
\text { tarefas, entrevistas, pesquisa } \\
\text { bibliográfica, } \\
\text { documental, estudo de caso. }\end{array}$ \\
\hline Arquivologia & Não citados. & Não citados. \\
\hline $\begin{array}{l}\text { Sistemas de } \\
\text { Informação }\end{array}$ & Parlamento (Assembleia) & Questionário \\
\hline
\end{tabular}

Fonte: Dados da pesquisa.

Nota: Dos 95 resumos que relatavam estudos empíricos ou relatos de experiência, 44 apresentavam as técnicas de pesquisa ou intervenção na Biblioteconomia e CI, e outros 14 em Museologia. Foram incluídas as recorrências das classificações dos locais de realização das pesquisas empíricas ou das intervenções entre parêntesis, no quadro.

Nota-se, no quadro 3, que os estudos empíricos e relatos de experiência das áreas em questão se diferem qualitativamente: as pesquisas na área de CI e Biblioteconomia se referem a equipamentos informacionais como bibliotecas, escolas, organizações e redes (como as redes 


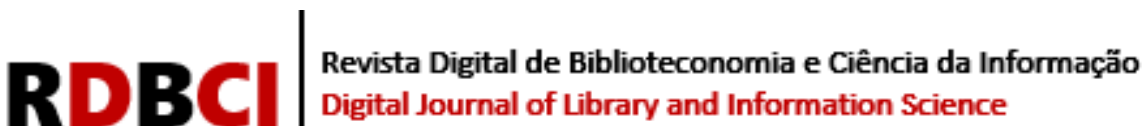

sociais digitais), enquanto a pesquisa em Museologia, diz respeito a museus, sítios arqueológicos, grupos culturais. Os cenários não institucionalizados, referenciados por Silva (2009), que apontam para formas de mediação pós-custodial, ou para mediações extra-institucionais estão presentes, como é o caso da referência às redes, grupos e movimentos sociais, especialmente na Biblioteconomia e CI. No entanto, os cenários institucionalizados estão fortemente presentes na abordagem da temática. A referência às escolas é presente, refletindo a existência da parceria museu-escola, para realização de ações de mediação (especialmente as educativas) e biblioteca-escola, como no caso da biblioteca escolar.

Quanto às técnicas de pesquisa utilizadas, há técnicas de pesquisa convergentes observação participante e não participante, análise de tarefas, entrevistas - e divergentes histórias orais, entrevistas narrativas, rodas de conversa, pesquisas documentais e estudos de caso (Museologia) em contraste com oficinas, pesquisa censitária e questionários (Biblioteconomia). O dado presente no quadro 3, referente à área de Sistemas de Informação, não é conclusivo, pois se refere a apenas um artigo que relatou técnica de pesquisa no resumo. Já os artigos da Arquivologia não citaram técnicas para serem reportadas, apresentando cunho teórico. Apesar das convergências, é possível visualizar, na tabela 2, abaixo, que há algumas diferenças para realização de pesquisas empíricas e relatos de experiência de mediação nas áreas de Museologia e Biblioteconomia e Ciência da Informação. Nota-se que em termos relativos, é maior o uso de questionários na área de CI e B em relação à área de Museologia e que esta utilizou mais a observação participante, entrevista, entrevista narrativa ou história oral, realização de tarefas e revisão bibliográfica e documental com maior freqüência relativa em relação às utilizadas em Biblioteconomia e CI.

Tabela 2. Técnicas de pesquisa presentes em relatos de experiência e estudos empíricos

\begin{tabular}{|c|c|c|c|c|c|c|c|c|c|c|c|}
\hline & \begin{tabular}{|l|} 
Observação \\
não \\
participante
\end{tabular} & $\begin{array}{l}\text { Observação } \\
\text { participante }\end{array}$ & Entrevista & $\begin{array}{l}\text { Entrevista } \\
\text { narrativa } \\
\text { ou história } \\
\text { oral }\end{array}$ & Oficina & $\begin{array}{l}\text { Realização } \\
\text { de tarefas }\end{array}$ & Questionário & $\begin{array}{l}\text { Revisão } \\
\text { bibl ou } \\
\text { doc. }\end{array}$ & $\begin{array}{l}\text { Roda de } \\
\text { conversa }\end{array}$ & Outros & Total \\
\hline \multicolumn{12}{|l|}{$\mathrm{CI}$ e B } \\
\hline $\begin{array}{l}\text { Relatos de } \\
\text { experiência }\end{array}$ & 3 & 2 & 2 & 0 & 3 & 6 & 2 & 1 & 0 & 4 & \\
\hline $\begin{array}{l}\text { Estudos } \\
\text { empíricos }\end{array}$ & 3 & 3 & 2 & 0 & 1 & 1 & 7 & 1 & 0 & 0 & \\
\hline Total & 6 & 5 & 4 & 0 & 4 & 7 & 9 & 2 & 0 & 4 & 41 \\
\hline$\%$ Relativo & 14,63 & 12,20 & 9,76 & 0,00 & 9,76 & 17,07 & 21,95 & 4,88 & 0,00 & 9,76 & $100 \%$ \\
\hline \multicolumn{12}{|l|}{ Mus } \\
\hline $\begin{array}{l}\text { Relatos de } \\
\text { experiência }\end{array}$ & 2 & 2 & 2 & 1 & 0 & 4 & 0 & 4 & 1 & 1 & \\
\hline $\begin{array}{l}\text { Estudos } \\
\text { empíricos }\end{array}$ & 0 & 2 & 1 & 1 & 0 & 1 & 0 & 1 & 0 & 0 & \\
\hline Total & 2 & 4 & 3 & 2 & 0 & 5 & 0 & 5 & 1 & 1 & 23 \\
\hline$\%$ Relativo & 8,70 & 17,39 & 13,04 & 8,70 & 0,00 & 21,74 & 0,00 & 21,74 & 4,35 & 4,35 & $100 \%$ \\
\hline
\end{tabular}

Fonte: Dados da pesquisa.

Notas: É importante notar que o total calculado diz respeito ao total de citações das técnicas e não corresponde ao total de artigos de cada área. O percentual relativo é razão do total das técnicas citadas em relação a cada tipo de técnica quantificada. Foram usadas abreviaturas na tabela: CI e B referem-se à Ciência da Informação e Biblioteconomia; Mus refere-se à Museologia; Revisão Bibl. ou docum. refere-se à revisão bibliográfica ou documental.

No que diz respeito às referências teóricas citadas nos resumos, como se pode notar no quadro 4, não há convergência teórica entre os autores presentes nos resumos das áreas de $\mathrm{CI}$ e Biblioteconomia, em relação à área de Museologia, à exceção de Giroux. Na área de Museologia, nota-se que os alguns autores interfaceiam com a Educação, História e Psicologia 


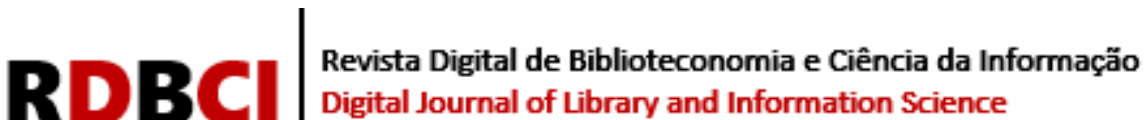

Social. Na área de CI e Biblioteconomia, além dos pesquisadores do campo (González de Gomes, Capurro, Le Coadic), há outros das áreas de Comunicação, Filosofia, Arquivologia, Sociologia.

Quadro 4. Autores citados como referência teórica nos resumos

\begin{tabular}{|c|c|}
\hline Área & Referenciais citados \\
\hline $\begin{array}{l}\text { Ciência da } \\
\text { Informação e } \\
\text { Biblioteconomia }\end{array}$ & $\begin{array}{l}\text { González de Gomez; Pierre Lévy; Deleuze; Lovelock; Le Coadic; Wright; Vergueiro; } \\
\text { D’Affonseca; Condemarian; Blonquist, Foucambert, Calafange; Nutti; Freitas; Santos; } \\
\text { Navas; Simeão; Almeida Junior; Masetto; Henri Giroux (1), Rafael Capurro; C.A.A.Araújo; } \\
\text { Partridge, Helen; Lee, Julie; Munro, Carrie; M. Egan E J. Shera; Habermas (3); Edgar Morin; } \\
\text { Foucault; Althusser; Freud; Lacan; Gesner; John Dury; Régis Debray; Echeverria; Flores; } \\
\text { Maturana; Barbero ; Benor, Harrison E Baxter; Ginzburg;Bauman; Ortega y Gasset. }\end{array}$ \\
\hline Museologia & $\begin{array}{l}\text { Paul Otlet; Dean, Davallon, Wagensberg; Emmanuel Lévinas, Jean Piaget, Vygotsky, Paulo } \\
\text { Freire; Charles Esche; Arendt; Giroux (1); Stuart Hall, Maurice Halbwachs; Paul Ricouer, e } \\
\text { Pierre Bourdieu. }\end{array}$ \\
\hline Arquivologia & Não citado \\
\hline $\begin{array}{ll}\text { Sistemas } & \text { de } \\
\text { Informação } & \end{array}$ & Não citado \\
\hline
\end{tabular}

Fonte: Dados da pesquisa.

Notas: Dados construídos por leitura dos 27 resumos que apresentavam referência direta a autores como referencial teórico. Autores que aparecem citados mais de uma vez estão com o número de recorrências entre parênteses, no quadro, e são apenas dois: Habermas, citado três vezes em Biblioteconomia e CI e Henri Giroux, citado uma vez nos resumos da área de Museologia e uma vez nos resumos de Biblioteconomia e CI.

Com relação aos sentidos com que a mediação tem sido abordada, a pesquisa aqui realizada classificou os resumos por meio da análise de conteúdo, enquadrando cada um deles em uma abordagem de mediação, conforme apresentada no quadro 2 da seção anterior deste artigo. Embora o resumo pudesse apontar para mais de uma forma de mediação, foi escolhida aquela predominante ou de maior destaque, pois o procedimento de análise de conteúdo de Bardin (1988) preconiza a indicação de uma classificação por unidade de análise de conteúdo: sendo a unidade de análise todo o resumo, uma classificação foi dada para ela - se se tratava de referência à mediação enquanto processo macrossocial, se processo institucional ou situacional. Os resultados da classificação encontram-se na tabela 3.

Tabela 3. Formas de mediação presentes por área de estudo

\begin{tabular}{l|l|l|l}
\hline Área & Formas de mediação & Detalhamento \\
\hline $\begin{array}{l}\text { Ciência da } \\
\text { Biblioteconomia }\end{array}$ & $\begin{array}{l}\text { Processo macrossocial } \\
\text { (vertical social) }\end{array}$ & 3 & $\begin{array}{l}\text { Discute a mediação cultural (políticas públicas de cultura; } \\
\text { atuação de Arquivos na cultura; conceitos de mediação } \\
\text { cultural e de mediação da arte). Relata processos de } \\
\text { mediação social (intervenções para criação de blogs } \\
\text { comunitários, melhoria de condições de cidadania, } \\
\text { mediação da leitura em contextos comunitários, } \\
\text { possibilidades de inclusão social). Discute papel de } \\
\text { veículos de comunicação social no contexto social. Discute } \\
\text { oconceito de mediação, no geral. Discute a mediatização da } \\
\text { cultura. }\end{array}$ \\
\hline $\begin{array}{l}\text { Processos } \\
\text { institucionais } \\
\text { (vertical institucional) }\end{array}$ & 2 & $\begin{array}{l}\text { Discute a mediação informacional (conceito, mediação } \\
\text { informacional em práticas arquivísticas, mediação no } \\
\text { mercado de capitais); mediação da leitura e formação do }\end{array}$ \\
\hline
\end{tabular}




\section{RDBCI \\ Digital Journal of Library and Information Science}

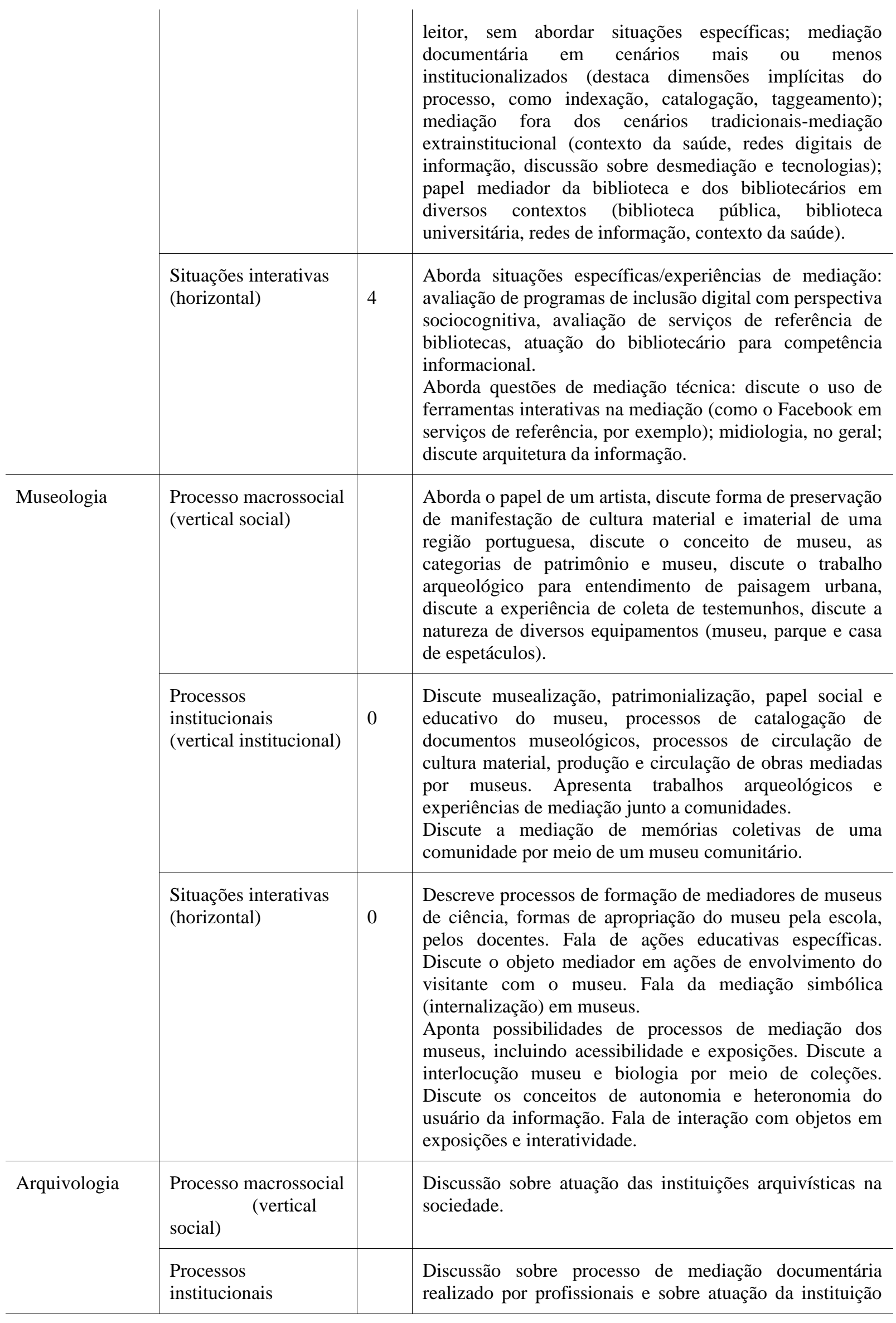




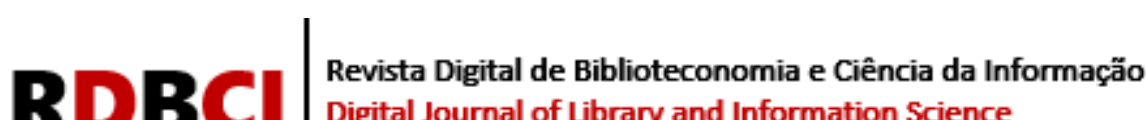 \\ Digital Journal of Library and Information Science}

\begin{tabular}{l|l|l|l} 
& (vertical institucional) & & arquivística em relação às suas missões institucionais. \\
\hline $\begin{array}{l}\text { Situações interativas } \\
\text { (horizontal) }\end{array}$ & $\begin{array}{l}\text { Não foram apresentados resumos com relatos de processos } \\
\text { de mediação sociocognitiva e técnica em relação a usuários } \\
\text { e públicos. }\end{array}$ \\
\hline $\begin{array}{l}\text { Sistemas de } \\
\text { Informação }\end{array}$ & $\begin{array}{l}\text { Processo macrossocial } \\
\text { (vertical social) }\end{array}$ & $\begin{array}{l}\text { Não aparecem discussões do papel ou função social dos } \\
\text { sistemas e suas formas de mediação. }\end{array}$ \\
\cline { 2 - 3 } & $\begin{array}{l}\text { Processos } \\
\text { institucionais } \\
\text { (vertical institucional) }\end{array}$ & $\begin{array}{l}\text { Discute a atuação da TI em processos de governança, no } \\
\text { geral. }\end{array}$ \\
\cline { 2 - 4 } & $\begin{array}{l}\text { Situações interativas } \\
\text { (horizontal) }\end{array}$ & $\begin{array}{l}\text { Discute projetos de apropriação da TI na Educação à } \\
\text { Distância e entre idosos. }\end{array}$ \\
\hline
\end{tabular}

Fonte: dados da pesquisa, compilados por meio de análise de conteúdo dos resumos recuperados.

Conforme se nota na tabela 2, confirma-se a diversidade de abordagens do tema mediação, em todas as áreas em estudo: tanto se referem a discussões mais amplas do papel das instituições na sociedade e para a cultura (processos macrossociais, relativos à mediação vertical), quanto a processos que a atuação institucional em diversas frentes de atuação em relação a usuários e públicos (processos institucionais, no eixo vertical), destacando-se os processos de mediação documentária, mediação da leitura, para CI e Biblioteconomia e de musealização e patrimonialização, para a Museologia. No que diz respeito a situações relatadas de mediação, na área de Museologia, as ações educativas, que exigem mediações sociocognitivas, têm destaque, e as questões de mediação técnica e de avaliação de serviços, na CI e Biblioteconomia. Por ter um volume muito restrito de trabalhos a serem analisados, as áreas de Arquivologia e de Sistemas de Informação são dificilmente comparáveis às outras, carecendo de ampliação do debate em torno das mediações nestas áreas. No entanto, destaca-se a ausência de discussões mais ampliadas da mediação em TI, em termos macrossociais, e a carência de discussões mais situacionais concretas de atuação na Arquivologia.

\section{CONSIDERAÇÕES FINAIS}

O ambicioso objetivo do artigo - apresentar um panorama geral de como as mediações, enquanto temática transversal na área de Ciência da Informação (CI), Museologia, Arquivologia, Biblioteconomia e Sistemas de Informação têm sido abordadas nessas disciplinas - foi cumprido. Nota-se que a temática se refere a todas as formas de mediação problematizadas ao longo do texto, em sua seção 2: há trabalhos que versam sobre a mediação cultural, mediatização, mediações institucionais (sejam documentárias, mediação da leitura, processos de musealização, mediação de instituições tradicionais em processos comunitários) e não institucionais e pós-custodiais (como os referentes às mediações sociais, formação de redes, laços comunitários sem referência explícita a atuações de instituições tradicionais). Confirma-se que a discussão sobre a mediação na área de Sistemas de Informação é incipiente, e na área de Arquivologia, nascente.

As dimensões da mediação - do eixo horizontal-situacional ao eixo vertical (macrossocial e institucional) - são relacionadas, embora se note a ênfase ora em situações interativas com relatos de experiência, ora discussões que relatam questões macrossociais em interação com as ordens institucionais. A discussão focalizada de mediação documentária, 


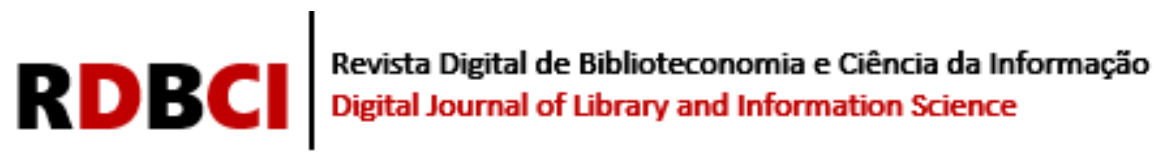

tomada especificamente em processos de mediação implícita não predomina nos trabalhos. De fato, não é possível estabelecer uma forma de mediação predominante entre os resumos lidos e classificados.

O vôo panorâmico é a limitação deste estudo, assim como da própria temática das mediações: ao abarcar processos tão distintos, como os de ordem macrossocial, institucional e situacional, perde-se a especificidade e possibilidade de aprofundamento em termos teóricos e metodológicos das práticas de mediação. Trabalhos futuros em perspectivas mediadoras, a partir deste, apontam para a necessidade de esmiuçar as especificidades de cada forma de mediação, por área de estudo, pois não se visualiza, claramente, intersecções que coloquem as discussões de Ciência da Informação-Biblioteconomia-Museologia-Arquivologia-Sistemas de Informação sob um mesmo denominador conceitual que seja o da Mediação.

\section{REFERÊNCIAS}

ALMEIDA, C. C. Mediação como processo semiótico: em busca de bases conceituais. In: ENCONTRO NACIONAL DE PESQUISA EM CIÊNCIA DA INFORMAÇÃO (ENANCIB), 13., 2012, Rio de Janeiro. Anais... Brasília: ANCIB, 2012. Disponível em:

https://brapci.inf.br/_repositorio/2015/04/pdf_c984eaa137_0013197.pdf. Acesso em: 15 jul. 2020.

ALMEIDA, M. A. Mediação cultural e da informação: Considerações socioculturais e políticas em torno de um conceito. In: ENCONTRO NACIONAL DE PESQUISA EM CIÊNCIA DA INFORMAÇÃO (ENANCIB), 8., 2007, Salvador. Anais... Brasília: ANCIB, 2007. Disponível em: http://www.ufpb.br/evento/index.php/enancib2016/enancib2016/paper/view/3505/2311.

Acesso em: 15 jul. 2020.

ALMEIDA JÚNIOR, Oswaldo Francisco de. Mediação da informação e múltiplas linguagens.

Pesq. bras. Ci. Inf., Brasília, v.2, n.1, p.89-103, jan./dez. 2009.

ARAÚJO, C. A. A. Novo quadro conceitual para a Ciência da Informação: informação, mediações e cultura. In: ENCONTRO NACIONAL DE PESQUISA EM CIÊNCIA DA INFORMAÇÃO (ENANCIB), 17., 2016, Salvador. Anais... Brasília: ANCIB, 2016.

Disponível em:

http://www.ufpb.br/evento/index.php/enancib2016/enancib2016/paper/view/4027. Acesso em: 15 jul.2020.

BARDIN, Laurence. Analise de conteúdo. Lisboa: Edições 70, 1988. 225p.

BOURDIEU, Pierre; DARBEL, Alain. O amor pela arte: os museus de arte na Europa e seu público. Trad. Guilherme João de Freitas Ferreira. São Paulo: Editora da Universidade de São Paulo: Zouk, 2003, 243 p.

DAVALLON, J. A mediação: a comunicação em processo? Prisma.Com: revista de Ciência da Informação e da Comunicação do CETAC, n.4, p.1-34, jun.2007.Disponível em: http://revistas.ua.pt/index.php/prismacom/article/viewFile/645/pdf. Acesso em set. 2016.

FERREIRA, L. E.; ALMEIDA JÚNIOR, O. F. A mediação da informação no âmbito da arquivística. Perspectivas em Ciência da Informação, v.18, n.1, p. 158-167, jan./mar. 2013. 


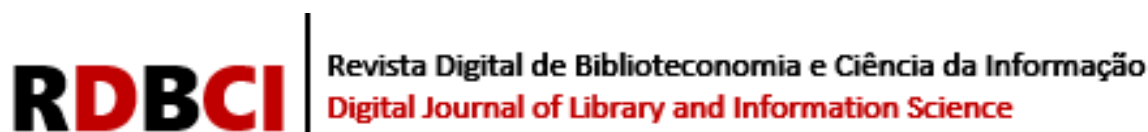

GOHN, Maria da Glória. Educação não-formal, participação da sociedade civil e estruturas colegiadas nas escolas. Ensaio: aval. pol. públ. Educ., Rio de Janeiro, v.14, n.50, p. 27-38, jan./mar. 2006.

HONORATO, Cayo. Mediação extrainstitucional. Museologia \& Interdisciplinaridade, Brasília: Revista do Programa de Pós-Graduação em Ciência da Informação da Universidade de Brasília, v. 3, n.6, mar./abr. 2015, p. 205-220. Disponível em: http://periodicos.unb.br/index.php/museologia/article/view/16737/15021. Acesso em: 15 jan. 2019.

LATOUR, Bruno. Reagregando o social: Uma introdução à teoria do ator-rede. Salvador Bauru: EDUFBA-EDUSC, 2012. 400 p.

LOPES, M. I. V. Mediação e recepção. Algumas conexões teóricas e metodológicas nos estudos latino-americanos de comunicação. MATRIZes, São Paulo, v. 8, n.1, p. 65-80, jan./jun. 2014.

LOUSADA, M. A mediação da informação e a arquivologia: aproximações teóricas. Pesq. Bras. em Ci. da Inf. e Bib., João Pessoa, v. 11, n. 1, p. 117 -134, 2016.

MARTÍN-BARBERO, Jesús. Dos meios às mediações - comunicação, cultura e hegemonia. [1987] 7. Ed. Rio de Janeiro: UFRJ, 2013. 356p.

MARTINS, Ana Amélia L. Mediação: reflexões no campo da Ciência da Informação. Agosto de 2010. 255 f. Dissertação- Universidade Federal de Minas Gerais- UFMG- Escola de Ciência da Informação- ECI. Belo Horizonte 18/08/2010.

ORTEGA, Cristina Dotta. Da mediação em Ciência da Informação. 2015. 121f. Dissertação (Relatório final de pesquisa de pós-doutoramento). Programa de Pós-Graduação em Ciência da Informação. Universidade Federal Fluminense - UFF, Niterói, Rio de Janeiro, 2015.

PERROTTI, E.; PIERUCCINI, I. Infoeducação: saberes e fazeres da contemporaneidade. In: LARA, M. L. G, FUJINO, A. NORONHA, D. P. (org.). Informação e contemporaneidade: perspectivas. Recife: Néctar, 2008. p. 46-97.

PERROTTI, E.; PIERUCCINI, I. A mediação cultural como categoria autônoma. Inf. Inf., Londrina, v. 19, n. 2, p. 1 - 22, maio/ago. 2014.

MARTELETO, R. M. Redes sociais, mediação e apropriação de informações: situando campos, objetos e conceitos na pesquisa em Ciência da Informação. Pesq. bras. ci. inf., Brasília, v.3, n.1, p.27-46, jan./dez. 2010.

MARTINS, Ana Amélia. Mediação: reflexões no campo da Ciência da Informação. 253f. (Dissertação de Mestrado). Programa de Pós-Graduação em Ciência da Informação. Escola de Ciência da Informação da Universidade Federal de Minas Gerais. 2010.

MARTINS, A. A. L. Mediação informacional: uma perspectiva a partir do campo social da informação. In: ENCONTRO NACIONAL DE PESQUISA EM CIÊNCIA DA INFORMAÇÃO, 17. Florianópolis. Anais... ANCIB, 2013. Disponível em: 


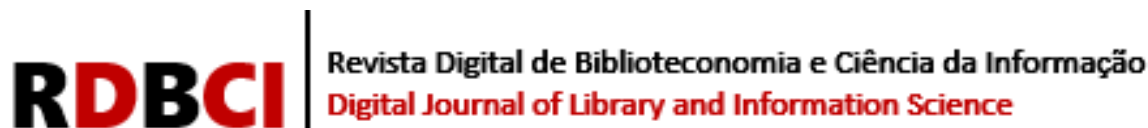

http://enancib.ibict.br/index.php/enancib/xivenancib/paper/view/4185/3308. Acesso em: 15 jul.2020.

PIOVEZAN, Nayane Martoni; CARDOSO, Lucila Moraes. Metaciência e cientometria da área de avaliação psicológica e educacional. Educare, Revista Cientifica de Educação, ISSN 2447-5432, v. 1, n. 1, 2015, p. 33-52. DOI:

http://dx.doi.org/10.19141/2447-5432/lumen.v1.n1.p.33-52.

ROCHA, E. C. F. Usuários e arquivos: problematizando as mediações. In: SIMPÓSIO TEMÁTICO ARQUIVOS \& EDUCAÇÃO, 1, 2016, Fortaleza. PARRELA, I. D.; KOYAMA, A. C. (org.). Arquivo e educação: experiências e pesquisas brasileiras em diálogo. Belo Horizonte: Escola de Ciência da Informação, Programa de Pós-graduação em Ciência da Informação, 2016. 145 p.

SILVA, Armando Malheiro da.; RIBEIRO, Fernanda. Das "ciências" documentais à ciência da informação. Ensaio epistemológico para um novo modelo curricular. 2 ed. Porto: Edições Afrontamento, 2008. 176 p.

SILVA, Armando Malheiro da. Mediações e mediadores em Ciência da Informação.

PRISMA.COM, n.9, p. 68-104, 2009. Disponível em

http://revistas.ua.pt/index.php/prismacom/article/view/700/pdf. Acesso em out.2017.

TUCHERMAN, I.; CAVALCANTI, C. C. B. Museus: dispositivos de curiosidade.

Comunicação, mídia e consumo, v.7, n.20, p. 141-158, 2010.

VARELA, Aida. Informação e autonomia: a mediação segundo Feuerstein. São Paulo: editora Senac, 2007. 368p.

\section{AGRADECIMENTOS}

A autora agradece aos alunos de iniciação científica envolvidos na pesquisa: Gustavo Augusto Andrade de Oliveira; Igor Cândido Costa; Larissa Caroline de Oliveira e Letícia Ferreira de Carvalho. A autora também agradece à UFMG pelo apoio recebido pelo Programa Institucional de Auxílio à Pesquisa de Docentes Recém-Contratados (ADRC) da UFMG para realização para realização de projeto correlato a este. 


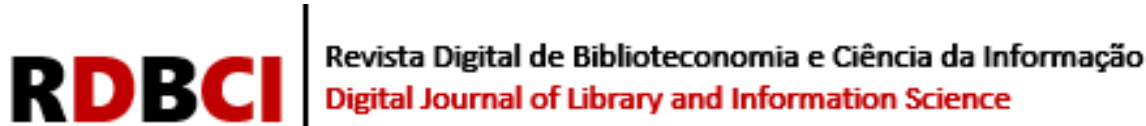

Artigo submetido ao sistema de similaridade 